\title{
The optimum dietary amino acid pattern for growing pigs
}

\author{
1. Experiments by amino acid deletion \\ BY T. C. WANG AND M. F. FULLER \\ Rowett Research Institute, Bucksburn, Aberdeen AB2 9SB
}

(Received 16 August 1988 - Accepted 20 January 1989)

\begin{abstract}
A series of four nitrogen-balance experiments was carried out with growing pigs to determine the optimum balance amongst the amino acids in the diet. The reduction in $\mathrm{N}$ retention when $20 \%$ of a single amino acid was removed from the diet was used to calculate a dietary amino acid pattern in which each amino acid would be equally limiting. A mixture of amino acids simulating the amino acid pattern of casein was used with the same efficiency as casein. From two successive deletion experiments an optimum balance amongst the essential amino acids was derived. Expressed relative to lysine $=100$ this had threonine 72 , valine 75 , methionine + cystine 63 , isoleucine 60 , leucine 110 , phenylalanine + tryosine 120 , tryptophan 18. No estimate was made for histidine. Essential amino acids in this pattern were mixed with non-essential amino acids in ratios of 36:64 up to 57:43. The highest efficiency of $N$ retention was achieved with diets having a ratio of at least $45: 55$. This included $(\mathrm{g} / 16 \mathrm{~g} \mathrm{~N})$ lysine $6 \cdot 5$, threonine $4 \cdot 7$, valine 4.9 , methionine + cystine $4 \cdot 1$, isoleucine $3 \cdot 9$, leucine $7 \cdot 2$, phenylalanine + tyrosine $7 \cdot 8$, tryptophan 12. The $\mathbf{N}$ of diets with this amino acid pattern was utilized significantly better than when the pattern proposed by the Agricultural Research Council (1981) was used. The flow of amino acids past the terminal ileum of pigs given the semi-synthetic diet with this amino acid pattern was no greater than that observed with protein-free diets. The proposed pattern thus describes the intrinsic requirements of the growing pig for absorbed amino acids.
\end{abstract}

Amino acids: Protein quality: Pig.

The quality of dietary protein is determined by its content of amino acids, and by their digestibility and availability. Quality can be considered as the degree to which the composition of the absorbed amino acid mixture accords with the balance required by the animal.

An optimum (or ideal) amino acid pattern is needed as a standard profile or reference protein when evaluating the quality of other dietary proteins. Since the nitrogen of essential amino acids can also be used in the synthesis of non-essential amino acids, a protein with essential amino acids in surplus relative to the non-essential amino acids may still support maximum $\mathrm{N}$ retention (NR). A more restricted definition of an ideal protein is one which includes the minimum quantity of each essential amino acid compatible with maximum utilization of the protein as a whole.

The question of the dietary amino acid pattern required by growing pigs has been reviewed in the past few years (Cole, 1978; Fuller, 1978; Cole et al. 1980; Henry, 1980; Low, 1980; Agricultural Research Council, 1981; Fuller \& Chamberlain, 1982; Wiesemüller, 1983; Yen et al. 1986). The experiments described here were designed to answer the question 'what is the optimum dietary amino acid balance for growing pigs?'. The optimum dietary amino acid profile is considered to be that which, for a given $\mathrm{N}$ intake (NI), results in the highest NR.

The method used is an extension of that published by Bender (1965) with rats. It is based on the concept that the removal of a non-limiting amino acid has no effect on NR. The changes in NR on removing a proportion of each amino acid in turn were used to calculate a dietary amino acid pattern in which all the amino acids were equally limiting. 
Table 1. Expt 1. Composition $(\mathrm{g} / \mathrm{kg})$ of diets

\begin{tabular}{|c|c|c|c|c|c|}
\hline Diet... & $\begin{array}{c}\text { (1) } \\
\text { Low-casein } \\
\text { (low-control) }\end{array}$ & $\begin{array}{c}\text { (2) } \\
\text { High-casein } \\
\text { (high-control) }\end{array}$ & $\begin{array}{l}\text { (3) } \\
\text { Low-casein } \\
+\mathrm{AA}\end{array}$ & $\begin{array}{c}\text { (4) } \\
\text { Low-casein } \\
+ \text { EAA }\end{array}$ & $\begin{array}{c}\text { (5) } \\
\text { Protein-free }\end{array}$ \\
\hline $\begin{array}{l}\text { Amino acid (AA) } \\
\text { mixture }\end{array}$ & - & - & $28 \cdot 59^{*}$ & $13.53 \dagger$ & - \\
\hline Casein & 128.65 & $160 \cdot 82$ & $128 \cdot 65$ & $128 \cdot 65$ & - \\
\hline Maize starch & $280 \cdot 00$ & $265 \cdot 00$ & $265 \cdot 06$ & $274 \cdot 12$ & $300 \cdot 00$ \\
\hline Glucose & 297.65 & $280 \cdot 48$ & $284 \cdot 00$ & 290.00 & $300 \cdot 00$ \\
\hline Sucrose & 137.00 & $137 \cdot 00$ & 137.00 & $137 \cdot 00$ & $150 \cdot 00$ \\
\hline Cellulose & $60 \cdot 00$ & $60 \cdot 00$ & $60 \cdot 00$ & $60 \cdot 00$ & $60 \cdot 00$ \\
\hline Vegetable oil & $40 \cdot 00$ & $40 \cdot 00$ & $40 \cdot 00$ & $40 \cdot 00$ & $40 \cdot 00$ \\
\hline $\begin{array}{l}\text { Mineral-vitamin } \\
\text { premix } \ddagger\end{array}$ & $56 \cdot 70$ & $56 \cdot 70$ & $56 \cdot 70$ & $56 \cdot 70$ & $56 \cdot 70$ \\
\hline Nitrogen $(\mathrm{g} / \mathrm{kg})$ & 17.60 & $22 \cdot 00$ & $20 \cdot 98$ & $19 \cdot 21$ & $0 \cdot 21$ \\
\hline $\mathrm{DE}(\mathrm{MJ} / \mathrm{kg})$ & $14 \cdot 10$ & 14.09 & $14 \cdot 09$ & 14.09 & $12 \cdot 75$ \\
\hline
\end{tabular}

EAA, essential amino acids; AA, amino acids; DE, digestible energy.

* Containing (g): aspartate $2 \cdot 319$, threonine $1 \cdot 076$, serine $1 \cdot 469$, glutamate $5 \cdot 637$, proline $3 \cdot 174$, glycine $0 \cdot 492$, alanine 0.754 , valine $1 \cdot 458$, cystine 0.130 , methionine 0.591 , isoleucine $1 \cdot 183$, leucine $2 \cdot 349$, tyrosine 1.485 , phenylalanine $1 \cdot 351$, lysine $2 \cdot 527$, histidine, $1 \cdot 029$, arginine $1 \cdot 214$, tryptophan 0.358 .

$\dagger$ As for *, but omitting aspartate, serine, glutamate, proline, glycine, alanine and arginine.

+ Supplying (per tonne): retinol $1.5 \mathrm{~g}$, cholecalciferol $25 \mathrm{mg}, \alpha$-tocopherol acetate $5 \mathrm{~g}$, phytylmenenaquinone $1 \mathrm{~g}$, thiamin $2 \mathrm{~g}$, riboflavin $3.4 \mathrm{~g}$, nicotinic acid $19 \mathrm{~g}$, pyridoxine $2.73 \mathrm{~g}$, vitamin $\mathrm{B}_{12} 21 \mathrm{mg}$, choline chloride $1150 \mathrm{~g}$, pantothenic acid $12 \mathrm{~g}$, biotin $50 \mathrm{mg}$, folic acid $2 \mathrm{~g}$, ascorbic acid $12 \mathrm{~g}$, salt $3.5 \mathrm{~kg}$, dicalcium phosphate $40 \mathrm{~kg}$, potassium bicarbonate $7 \mathrm{~kg}$, iron $80 \mathrm{~g}$, zinc $100 \mathrm{~g}$, manganese $40 \mathrm{~g}$, magnesium $420 \mathrm{~g}$, copper $150 \mathrm{~g}$, iodine $2 \mathrm{~g}$, cobalt $0.5 \mathrm{~g}$, selenium $0.15 \mathrm{~g}$.

\section{MATERIALS AND METHODS}

There were four $\mathrm{N}$ balance trials for which, except where otherwise indicated, the experimental procedure was the same. In Expt 5 the digestibilities of amino acids in the experimental diet were estimated.

\section{Animals}

In Expts 1,2, 3 and 4, the number of gilts used was eighteen, twenty-four, twenty and twenty respectively. Their starting weights were $25-30 \mathrm{~kg}$ and their finishing weights $45-50 \mathrm{~kg}$. All were Large White $\times$ (Landrace $\times$ Large White) from the Rowett Institute herd.

\section{Housing and cages}

At $7 \mathrm{~d}$ before the first urine collection the pigs were moved into metabolism cages to adjust to their new environment. The room temperature was controlled at $22-24^{\circ}$. Water was supplied ad lib. through nipple drinkers.

\section{Experimental diets}

Expt 1 . Of the $\mathrm{N}$ in casein $20 \%$ was replaced by synthetic amino acids in the same proportions as in casein to confirm that the free amino acids used in this way gave a similar rate of NR to intact protein. The diets used in Expt 1 are shown in Table 1. At the end of the measurement period all animals were fed on a protein-free diet for $11 \mathrm{~d}(4 \mathrm{~d}$ adjustment and $7 \mathrm{~d}$ collection of urine and faeces) to measure the obligatory $\mathrm{N}$ losses.

Expt 2. Casein protein was used to provide the control amino acid pattern. The diets supplied $1.4 \mathrm{~g} \mathrm{~N} / \mathrm{kg}$ body-weight $(\mathrm{BW})^{\mathbf{0} 75}$ per $\mathrm{d}$ in the high-control diet (treatment 1 ) and $1.05 \mathrm{~g} \mathrm{~N} / \mathrm{kg} \mathrm{BW}^{0.75}$ per $\mathrm{d}$ in the low-control diet (treatment 12). To provide diets in which 
Table 2. Expt 2. Composition $(\mathrm{g} / \mathrm{kg})$ of diets*

\begin{tabular}{|c|c|c|c|c|c|c|}
\hline Diet ... & $\begin{array}{l}\text { (1) } \\
\text { High- } \\
\text { control }\end{array}$ & $\begin{array}{c}\text { (2) } \\
\text { Threonine }\end{array}$ & $\begin{array}{c}(3) \\
\text { Valine }\end{array}$ & $\begin{array}{c}\text { (4) } \\
\text { Methionine }+ \\
\text { cystine }\end{array}$ & $\begin{array}{c}\text { (5) } \\
\text { Isoleucine }\end{array}$ & $\begin{array}{c}\text { (6) } \\
\text { Leucine }\end{array}$ \\
\hline Amino acid mixture & 0 & $26 \cdot 61$ & $26 \cdot 68$ & $26 \cdot 42$ & $26 \cdot 52$ & $26 \cdot 21$ \\
\hline Casein & $110 \cdot 91$ & $83 \cdot 18$ & $83 \cdot 18$ & $83 \cdot 18$ & $83 \cdot 18$ & $83 \cdot 18$ \\
\hline Maize starch & $297 \cdot 39$ & $298 \cdot 51$ & 298.44 & $298 \cdot 70$ & $298 \cdot 60$ & 298.91 \\
\hline Glucose & $300 \cdot 00$ & $300 \cdot 00$ & $300 \cdot 00$ & $300 \cdot 00$ & $300 \cdot 00$ & $300 \cdot 00$ \\
\hline Sucrose & $130 \cdot 00$ & 130.00 & $130 \cdot 00$ & $130 \cdot 00$ & $130 \cdot 00$ & $130 \cdot 00$ \\
\hline Cellulose & $65 \cdot 00$ & 65.00 & $65 \cdot 00$ & 65.00 & $65 \cdot 00$ & 65.00 \\
\hline Vegetable oil & $40 \cdot 00$ & $40 \cdot 00$ & $40 \cdot 00$ & $40 \cdot 00$ & $40 \cdot 00$ & $40 \cdot 00$ \\
\hline $\begin{array}{l}\text { Mineral-vitamin } \\
\text { premix } \dagger\end{array}$ & $56 \cdot 70$ & $56 \cdot 70$ & $56 \cdot 70$ & $56 \cdot 70$ & 56.70 & $56 \cdot 70$ \\
\hline Nitrogen $(\mathrm{g} / \mathrm{kg})$ & $15 \cdot 17$ & $14 \cdot 54$ & $14 \cdot 55$ & $14 \cdot 54$ & 14.54 & 14.52 \\
\hline \multirow[t]{3}{*}{$\mathrm{DE}(\mathrm{MJ} / \mathrm{kg})$} & $14 \cdot 11$ & $14 \cdot 11$ & $14 \cdot 11$ & $14 \cdot 11$ & 14.11 & $14 \cdot 11$ \\
\hline & (7) & (8) & (9) & (10) & (11) & (12) \\
\hline & $\begin{array}{c}\text { Phenylalanine }+ \\
\text { tyrosine }\end{array}$ & Lysine & Histidine & Tryptophan & $\begin{array}{c}\text { essential } \\
\text { amino acids }\end{array}$ & $\begin{array}{l}\text { Low- } \\
\text { control }\end{array}$ \\
\hline Amino acid mixture & $41 \cdot 52$ & 27.53 & $27 \cdot 38$ & 26.59 & 11.74 & 0 \\
\hline Casein & $66 \cdot 55$ & $83 \cdot 18$ & $83 \cdot 18$ & $83 \cdot 18$ & $83 \cdot 18$ & $83 \cdot 18$ \\
\hline Maize starch & $300 \cdot 23$ & 297.59 & $297 \cdot 74$ & 298.53 & $313 \cdot 38$ & $325 \cdot 12$ \\
\hline Glucose & $300 \cdot 00$ & $300 \cdot 00$ & $300 \cdot 00$ & $300 \cdot 00$ & $300 \cdot 00$ & $300 \cdot 00$ \\
\hline Sucrose & 130.00 & 130.00 & $130 \cdot 00$ & $130 \cdot 00$ & $130 \cdot 00$ & $130-00$ \\
\hline Cellulose & 65.00 & 65.00 & $65 \cdot 00$ & 65.00 & 65.00 & $65 \cdot 00$ \\
\hline Vegetable oil & $40 \cdot 00$ & $40 \cdot 00$ & $40-00$ & $40 \cdot 00$ & $40 \cdot 00$ & $40 \cdot 00$ \\
\hline $\begin{array}{l}\text { Mineral-vitamin } \\
\text { premix } \dagger\end{array}$ & $56 \cdot 70$ & $56 \cdot 70$ & $56 \cdot 70$ & $56 \cdot 70$ & $56 \cdot 70$ & $56 \cdot 70$ \\
\hline $\mathrm{N}(\mathrm{g} / \mathrm{kg})$ & $14 \cdot 18$ & $14 \cdot 48$ & $14 \cdot 51$ & $14 \cdot 54$ & $12 \cdot 90$ & $11 \cdot 50$ \\
\hline $\mathrm{DE}(\mathrm{MJ} / \mathrm{kg})$ & $14 \cdot 11$ & $14 \cdot 11$ & $14 \cdot 11$ & $14 \cdot 11$ & $14 \cdot 13$ & $14 \cdot 14$ \\
\hline
\end{tabular}

$\mathrm{DE}$, digestible energy.

* Diet (1), high-control, casein-protein only; diet (12), low-control, casein-protein only; diets (2)-(10), the amino acid omitted from the level of amino acids of the high-control pattern to the low-control pattern level $(22 \%$ of that in high-control); diet (7), omitting $36 \%$ of the tyrosine and phenylalanine from the high-control pattern; diet (11), omitting all non-essential amino acids from the supplement.

+ For details, see Table 1 .

each essential amino acid was reduced from the high-control to the low-control level, diets 2-10 were made by adding to the low-control diet a mixture of synthetic amino acids including all but one of the essential amino acids, together with aspartate, glutamate and alanine, each supplying one-third of the $\mathrm{N}$ needed to restore the total $\mathrm{N}$ to the concentration in the high-control diet. In treatment 11 these non-essential amino acids were omitted. Because casein protein is high in phenylalanine and tyrosine relative to other amino acids, according to preliminary estimation of an optimal balance (Agricultural Research Council, 1981), 36\% of these amino acids were omitted to form treatment 7 . The compositions of the diets used in Expt 2 are given in Table 2. From the results the quantity of each amino acid that could be removed without effect on $\mathrm{N}$ retention was calculated. These estimates were used to formulate a pattern closer to the ideal than that of casein. For this purpose the simple linear model shown in Fig. 1 was used. In this model it is assumed that (1) removal of the first limiting amino acid (as A in Fig. 1) would reduce NR to the greatest extent; (2) if removal of an amino acid did not reduce NR at all (as C in Fig. 1), then the quantity removed was in excess relative to the first limiting amino acid; (3) if removal of 


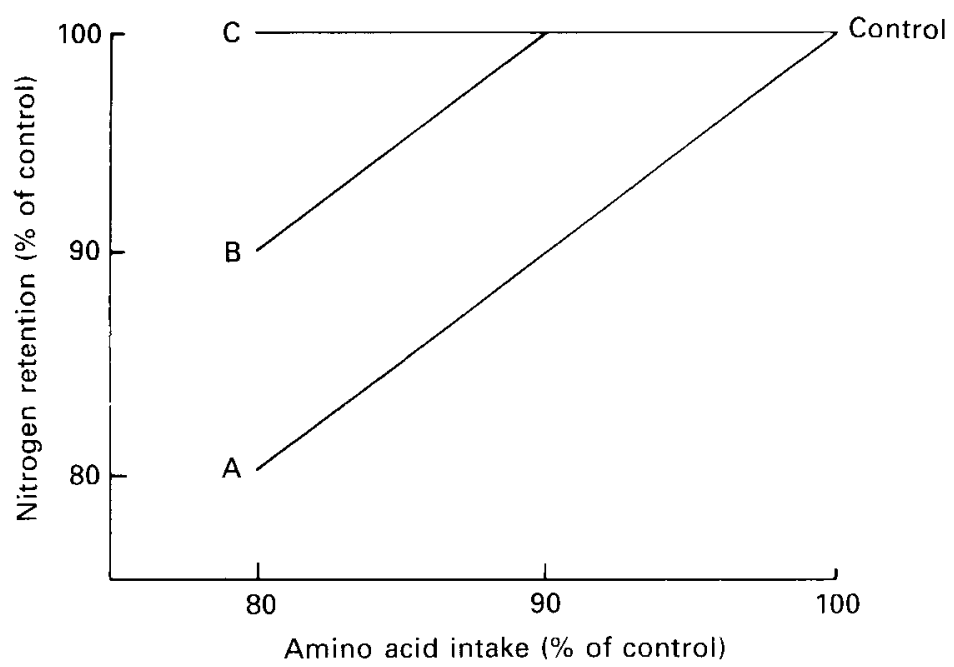

Fig. 1. Principle of the method of determining amino acid requirements by deduction. A is the first limiting amino acid; $\mathrm{B}$ and $\mathrm{C}$ are amino acids which are respectively 10 and $>20 \%$ in excess relative to $\mathrm{A}$.

an amino acid resulted in a reduction in NR intermediate between 1 and 2 (as B in Fig. 1) then the proportion that could have been removed without reducing NR could be interpolated proportionately.

The resulting estimates were used to form a provisional 'ideal' pattern. Because the quantity of some amino acids removed from the control pattern in Expt 2 did not affect NR, it was not possible to calculate from the results a pattern of equally limiting amino acids. Thus the provisional ideal pattern was tested in the third experiment.

Expt 3. In this experiment another $20 \%$ of each essential amino acid was removed in turn from the new pattern. The compositions of the diets used in Expt 3 are given in Table 3. The results of the third experiment were again used to make a second estimate of the ideal amino acid pattern, i.e. in which each essential amino acid would be equally limiting. This new pattern was used as the basis of the fourth experiment.

Expt 4. Four diets were formulated in which the essential amino acids were in the pattern derived from Expt 3 and in which the ratio of their sum : the sum of the non-essential amino acids was varied from $36: 64$ to $57: 43$, corresponding to $5,6,7$ and $8 \mathrm{~g}$ lysine $/ 16 \mathrm{~g} \mathrm{~N}$. The pattern proposed as 'ideal protein' by the Agricultural Research Council (1981), which contained $7 \mathrm{~g}$ lysine $/ 16 \mathrm{~g} \mathrm{~N}$, was also included in this experiment. All these diets supplied the same amount of $\mathrm{N}$. The compositions of the diets in Expt 4 are given in Table 4.

\section{Feeding}

The animals were given the diets at the rate of $93 \mathrm{~g} / \mathrm{kg} \mathrm{BW}^{0.75}$ per $\mathrm{d}$ in three equal meals each with 0.8 litres water. The feeding times were $08.30,12.30$ and 17.30 hours. All pigs received their experimental diets for $7 \mathrm{~d}$, made up of a $3 \mathrm{~d}$ preliminary period and $4 \mathrm{~d}$ of collection, except that the preliminary period before the collection of urine in the first period was $7 \mathrm{~d}$.

\section{Collections and measurement}

Before the first collection bladder catheters were introduced as described by Fuller et al. (1979). In each period urine was collected continuously into acid (250 $\mathrm{ml} 2 \mathrm{M}$-sulphuric 
Table 3. Expt 3. Compositions $(\mathrm{g} / \mathrm{kg})$ of diets

\begin{tabular}{|c|c|c|c|c|c|}
\hline Diet ... & $\begin{array}{c}\text { (1) } \\
\text { High- } \\
\text { control }\end{array}$ & $\begin{array}{l}\text { (2) } \\
\text { Threonine }\end{array}$ & $\begin{array}{c}\text { (3) } \\
\text { Valine }\end{array}$ & $\begin{array}{l}\text { (4) } \\
\text { Methionine } \\
+ \text { cystine }\end{array}$ & $\begin{array}{c}\text { (5) } \\
\text { Isoleucine }\end{array}$ \\
\hline $\begin{array}{l}\text { Amino acid } \\
\text { mixture* }\end{array}$ & $80 \cdot 21$ & $80 \cdot 33$ & $80 \cdot 36$ & $80 \cdot 19$ & $80 \cdot 25$ \\
\hline Casein & $43 \cdot 15$ & $43 \cdot 15$ & $43 \cdot 15$ & $43 \cdot 15$ & $43 \cdot 15$ \\
\hline Maize starch & $288 \cdot 94$ & $288 \cdot 82$ & $288 \cdot 79$ & 288.96 & $288 \cdot 90$ \\
\hline Glucose & $295 \cdot 00$ & 295.00 & 295.00 & $295 \cdot 00$ & $295 \cdot 00$ \\
\hline Sucrose & 136.00 & $136 \cdot 00$ & $136 \cdot 00$ & $136 \cdot 00$ & $136 \cdot 00$ \\
\hline Cellulose & $60 \cdot 00$ & $60 \cdot 00$ & 60.00 & $60 \cdot 00$ & $60 \cdot 00$ \\
\hline Vegetable oil & $40 \cdot 00$ & $40 \cdot 00$ & $40 \cdot 00$ & $40 \cdot 00$ & $40-00$ \\
\hline $\begin{array}{l}\text { Mineral-vitamin } \\
\text { premix } \dagger\end{array}$ & $56 \cdot 70$ & $56 \cdot 70$ & $56 \cdot 70$ & $56 \cdot 70$ & $56 \cdot 70$ \\
\hline Nitrogen $(\mathrm{g} / \mathrm{kg})$ & $14 \cdot 52$ & $14 \cdot 52$ & $14 \cdot 52$ & $14 \cdot 52$ & $14 \cdot 52$ \\
\hline \multirow[t]{3}{*}{$\mathrm{DE}(\mathrm{MJ} / \mathrm{kg})$} & $14 \cdot 11$ & $14 \cdot 11$ & $14 \cdot 11$ & $14 \cdot 11$ & $14 \cdot 11$ \\
\hline & (6) & (7) & (8) & (9) & $(10)$ \\
\hline & Leucine & $\begin{array}{c}\text { Phenylalanine }+ \\
\text { tyrosine }\end{array}$ & Lysine & Histidine & Tryptophan \\
\hline $\begin{array}{l}\text { Amino acid } \\
\text { mixture* }\end{array}$ & $80 \cdot 29$ & $80 \cdot 01$ & $80 \cdot 85$ & $80 \cdot 80$ & $80 \cdot 27$ \\
\hline Casein & $43 \cdot 15$ & $43 \cdot 15$ & $43 \cdot 15$ & $43 \cdot 15$ & $43 \cdot 15$ \\
\hline Maize starch & 288.86 & $289 \cdot 14$ & $288 \cdot 30$ & $288 \cdot 35$ & $288 \cdot 88$ \\
\hline Glucose & 295.00 & 295.00 & $295 \cdot 00$ & $295 \cdot 00$ & 295.00 \\
\hline Sucrose & $136 \cdot 00$ & 136.00 & $136 \cdot 00$ & $136 \cdot 00$ & 136.00 \\
\hline Cellulose & $60 \cdot 00$ & $60 \cdot 00$ & $60 \cdot 00$ & $60 \cdot 00$ & $60 \cdot 00$ \\
\hline Vegetable oil & $40 \cdot 00$ & $40 \cdot 00$ & $40 \cdot 00$ & $40 \cdot 00$ & $40 \cdot 00$ \\
\hline $\begin{array}{l}\text { Mineral-vitamin } \\
\text { premix } \dagger\end{array}$ & $56 \cdot 70$ & $56 \cdot 70$ & $56 \cdot 70$ & $56 \cdot 70$ & $56 \cdot 70$ \\
\hline $\mathrm{N}(\mathrm{g} / \mathrm{kg})$ & $14 \cdot 52$ & $14 \cdot 52$ & $14 \cdot 52$ & 14.52 & $14 \cdot 52$ \\
\hline $\mathrm{DE}(\mathrm{MJ} / \mathrm{kg})$ & $14 \cdot 11$ & $14 \cdot 11$ & $14 \cdot 11$ & $14 \cdot 11$ & $14 \cdot 11$ \\
\hline
\end{tabular}

* Diets (2)-(10) were formed by isonitrogenous replacement of amino acids by aspartate, glutamate and alanine (see p. 79 for details).

$\dagger$ For details, see Table 1 .

Table 4. Expt 4. Composition $(\mathrm{g} / \mathrm{kg})$ of diets

\begin{tabular}{|c|c|c|c|c|c|}
\hline $\begin{array}{r}\text { Diet ... } \\
\text { EAA: NEAA ... } \\
\text { Lysine }(\mathrm{g} / 16 \mathrm{~g} \mathrm{~N}) \ldots\end{array}$ & $\begin{array}{c}(1) \\
36: 64 \\
5 \cdot 0\end{array}$ & $\begin{array}{l}(2) \\
43: 57 \\
6 \cdot 0\end{array}$ & $\begin{array}{c}(3) \\
50: 50 \\
7 \cdot 0\end{array}$ & $\begin{array}{c}(4) \\
57: 43 \\
8 \cdot 0\end{array}$ & $\begin{array}{l}(5)^{*} \\
40: 60 \\
7 \cdot 0\end{array}$ \\
\hline Amino acid mixture & $63 \cdot 17$ & $46 \cdot 77$ & $30 \cdot 37$ & 13.97 & $52 \cdot 27$ \\
\hline Maize starch & 292.96 & $298 \cdot 13$ & $303 \cdot 30$ & $308 \cdot 46$ & 296.95 \\
\hline Casein & $56 \cdot 17$ & $67 \cdot 40$ & 78.63 & $89 \cdot 86$ & $63 \cdot 08$ \\
\hline Glucose & 295.00 & 295.00 & $295 \cdot 00$ & 295.00 & $295 \cdot 00$ \\
\hline Suctose & 136.00 & 136.00 & 136.00 & $136 \cdot 00$ & 136.00 \\
\hline Cellulose & 60.00 & 60.00 & $60 \cdot 00$ & 60.00 & $60 \cdot 00$ \\
\hline $\begin{array}{l}\text { Mineral-vitamin } \\
\text { premix }{ }^{\dagger}\end{array}$ & $56 \cdot 70$ & $56 \cdot 70$ & $56 \cdot 70$ & $56 \cdot 70$ & $56 \cdot 70$ \\
\hline Vegetable oil & $40 \cdot 00$ & $40 \cdot 00$ & $40 \cdot 00$ & $40 \cdot 00$ & $40 \cdot 00$ \\
\hline Nitrogen $(\mathrm{g} / \mathrm{kg})$ & $14 \cdot 52$ & $14 \cdot 52$ & $14 \cdot 52$ & $14 \cdot 52$ & 14.52 \\
\hline $\mathrm{DE}(\mathrm{MJ} / \mathrm{kg})$ & $14 \cdot 11$ & $14 \cdot 11$ & $14 \cdot 11$ & $14 \cdot 11$ & $14 \cdot 11$ \\
\hline
\end{tabular}

EAA, essential amino acids; NEAA, non-essential amino acids; DE, digestible energy.

* Pattern proposed by the Agricultural Research Council (1981).

$\dagger$ For details, see Table 1 . 
Table 5. Expt 5. Composition $(\mathrm{g} / \mathrm{kg})$ of diet

\begin{tabular}{lrcl}
\hline \hline & & & \\
Amino acid mixture* & 43.83 & Vegetable oil & $40 \cdot 00$ \\
Maize starch & 298.90 & Mineral-vitamin & $56 \cdot 70$ \\
Casein & $69 \cdot 57$ & premix $\dagger$ & \\
Glucose & 295.00 & Nitrogen $(\mathrm{g} / \mathrm{kg})$ & $14 \cdot 52$ \\
Sucrose & 136.00 & $\mathrm{DE}(\mathrm{MJ} / \mathrm{kg})$ & $14 \cdot 12$ \\
Cellulose & 60.00 & & \\
\hline
\end{tabular}

DE, digestible energy.

* Containing $(\mathrm{g})$ : aspartic acid $15 \cdot 17$, threonine $1 \cdot 63$, monosodium glutamate $19 \cdot 29$, alanine $1 \cdot 06$, valine $0 \cdot 48$, cystine $0 \cdot 16$, methionine $1 \cdot 31$, isoleucine $0 \cdot 14$, leucine $0 \cdot 82$, lysine hydrochloride $1 \cdot 72$, histidine $0 \cdot 60$, arginine $1 \cdot 20$, tryptophan $0 \cdot 26$.

+ See Table 1 for details.

acid) for $48 \mathrm{~h}$. The faeces were collected and preserved in acid in the last $10 \mathrm{~d}$ of each balance. Total $\mathrm{N}$ was analysed in the faeces and urine samples by the Kjeldahl method of Davidson et al. (1970). The amino acid composition of casein was measured by ionexchange chromatography (Spackman et al. 1958). A sample of casein was first treated with performic acid to oxidize methionine and cystine to methionine sulphone and cysteic acid (Moore, 1963). Both this and an unoxidized sample were hydrolysed in $6 \mathrm{~m}$-hydrochloric acid for $24 \mathrm{~h}$. A sample of casein was hydrolysed in $4 \mathrm{M}$-lithium hydroxide for $4 \mathrm{~h}$ for tryptophan analysis (Lucas \& Sotelo, 1980).

\section{Design}

Expt 1. Eighteen animals were formed into two blocks of nine on the basis of BW. Within each block four different treatments were tested in two periods, giving a total of nine observations with each treatment.

Expts 2 and 3. Two animals were given each treatment in three sequential periods, ensuring that no animal was on the same treatment twice. This gave a total of six observations per treatment.

Expt 4. Twenty animals were used for two periods to test five different treatments. Four animals were allocated to each treatment ensuring that no animal was on the same treatment twice. This resulted in eight observations per treatment.

Expt 5 . Eight gilts, weighing $45 \mathrm{~kg}$, fitted with simple ' $\mathrm{T}$ ' cannulas in the terminal ileum were used to measure the digestibility of amino acids. The diet was based on a mixture of synthetic amino acids added to casein to make the balanced amino acid pattern derived from the results of Expt 4. Measurements were also made on a protein-free diet (as in Table 1) and the values for daily amino acid flow were used to calculate the true digestibility of the amino acids in the test diet. Chromic oxide $(3 \mathrm{~g} / \mathrm{kg})$ was used as an indigestible marker. The composition of the diet is given in Table 5. At $7 \mathrm{~d}$ after the animals were introduced to the diet, an $8 \mathrm{~h}$ collection of digesta was made. Samples were frozen and then freeze-dried for analysis.

\section{Statistical analysis}

In each experiment, a regression analysis was made to determine the relation between NR and amino acid intake, using each set of amino acid values for animals with limiting intakes and those on the high-control diet, adjusting for the effects of animal, period and $\mathrm{N}$ intake. GENSTAT (Lawes Agricultural Trust, 1982) was used in all the statistical analyses. 
Table 6. Expt 1. Effect of replacing $20 \%$ casein-nitrogen by synthetic amino acids on $N$ balance in pigs

\begin{tabular}{|c|c|c|c|c|c|}
\hline Dietary treatment & NI & $\mathbf{U N}^{*}$ & NR* & $\mathrm{ABV}^{*}$ & $\mathrm{BV}^{*}$ \\
\hline High-casein & 1.988 & $0.658^{\mathrm{a}}$ & $1 \cdot 233^{a}$ & $0 \cdot 655^{\mathrm{a}}$ & $0 \cdot 738^{a}$ \\
\hline Low-casein (LC) & 1.592 & $0.439^{\mathrm{b}}$ & $1 \cdot 056^{b}$ & $0 \cdot 713^{\mathrm{b}}$ & $0.813^{b}$ \\
\hline $\mathrm{LC}+$ amino acids & 1.898 & $0.600^{\mathrm{a}}$ & $1 \cdot 201^{\mathrm{a}}$ & $0 \cdot 665^{a}$ & $0.753^{\mathrm{a}}$ \\
\hline $\begin{array}{l}\text { LC + essential } \\
\text { amino acids }\end{array}$ & 1.737 & $0.465^{b}$ & $\mathrm{~J} \cdot 176^{\mathrm{a}}$ & $0 \cdot 720^{\mathrm{b}}$ & $0 \cdot 812^{\mathrm{b}}$ \\
\hline Pooled SE & 0.0020 & 0.0175 & 0.0177 & 0.0104 & 0.0097 \\
\hline
\end{tabular}

a, b Means with different superscript letters differ significantly $(P<0-05)$.

NI, N intake (g/ $\mathrm{kg}$ body-weight (BW) ${ }^{0.75}$ per d); UN, urinary $\mathrm{N}$ excretion ( $\mathrm{g} / \mathrm{kg} \mathrm{BW} \mathrm{B}^{0.75}$ per d); $\mathrm{NR}, \mathrm{N}$ retention $\left(\mathrm{g} / \mathrm{kg} \mathrm{BW}^{0.75}\right.$ per d); $\mathrm{ABV}$, apparent biological value; $\mathrm{BV}$, biological value.

* Results adjusted for body-weight, period and animal.

Table 7. Expt 2. Nitrogen metabolism of pigs given diets with partial deletion of individual amino acids*

\begin{tabular}{|c|c|c|c|c|c|c|}
\hline Treatment & Diet & NI & UN† & $\mathrm{NR} \dagger$ & $\mathrm{ABV} \dagger$ & $\mathrm{BV} \dagger$ \\
\hline (1) & High-control & $1 \cdot 36$ & 0.28 & 0.89 & 0.75 & 0.88 \\
\hline (2) & Threonine & $1 \cdot 32$ & 0.45 & 0.72 & 0.62 & 0.75 \\
\hline (3) & Valine & $1 \cdot 31$ & 0.31 & 0.86 & 0.73 & 0.85 \\
\hline (4) & $\begin{array}{l}\text { Methionine + } \\
\text { cystine }\end{array}$ & $1 \cdot 31$ & 0.47 & 0.70 & 0.60 & 0.73 \\
\hline (5) & Isoleucine & 1.29 & $0 \cdot 30$ & 0.87 & 0.74 & $0 \cdot 86$ \\
\hline (6) & Leucine & $1 \cdot 30$ & 0.30 & 0.87 & 0.74 & 0.86 \\
\hline (7) & $\begin{array}{l}\text { Phenylalanine } \\
+ \text { tyrosine }\end{array}$ & $1 \cdot 26$ & 0.30 & 0.87 & 0.74 & 0.86 \\
\hline$(8)$ & Lysine & $1 \cdot 29$ & 0.27 & 0.90 & 0.76 & 0.88 \\
\hline (9) & Histidine & $1 \cdot 31$ & 0.24 & 0.93 & 0.79 & 0.91 \\
\hline (10) & Tryptophan & $1 \cdot 32$ & 0.27 & 0.90 & 0.76 & $0-88$ \\
\hline (11) & $\begin{array}{l}\text { Non-essential } \\
\text { amino acids }\end{array}$ & $1 \cdot 17$ & $0 \cdot 30$ & 0.87 & 0.77 & 0.87 \\
\hline (12) & Low-control & 1.32 & $0 \cdot 45$ & 0.72 & 0.64 & 0.75 \\
\hline & Pooled SE & 0.016 & 0.016 & 0.016 & 0.013 & 0.012 \\
\hline
\end{tabular}

$\mathrm{NI}, \mathrm{N}$ intake (g/kg body-weight ${ }^{0 \cdot 75}$ per d) $\mathrm{UN}$, urinary $\mathrm{N}\left(\mathrm{g} / \mathrm{kg}\right.$ body-weight ${ }^{0 \cdot 75}$ per $\left.\mathrm{d}\right) ; \mathrm{NR}, \mathrm{N}$ retention $(\mathrm{g} / \mathrm{kg}$ body weight ${ }^{0.75}$ per d); $\mathrm{ABV}$, apparent biological value; $\mathrm{BV}$, biological value.

* Diet (1), high-control, casein-protein only; diet (12), low-control, casein-protein only; diets (2) (10), the amino acid omitted from the level of amino acids of the high-control pattern to the low-control pattern level $(22 \%$ of that in high-control); diet (7), omitting $36 \%$ of the tyrosine and phenylalanine from the high-control pattern; diet (11), omitting all non-essential amino acids from the supplement.

+ Means adjusted for the effects of period and $\mathrm{N}$ intake.

\section{RESULTS \\ Expt 1}

Mean results showing a comparison of the four treatments in Expt 1 are given in Table 6. These show the $\mathrm{N}$ intake (NI), urinary $\mathrm{N}$ excretion (UN), NR, apparent biological value (ABV) and biological value (BV). The UN and faecal N (FN), of pigs given the proteinfree diet, were 0.132 (SE 0.0172) and 0.112 (SE 0.0246) $\mathrm{g} / \mathrm{kg} \mathrm{BW}^{0.75}$ per d respectively. There was a slight difference in NI between treatments 2 (high-casein) and 3 (low-casein + free 


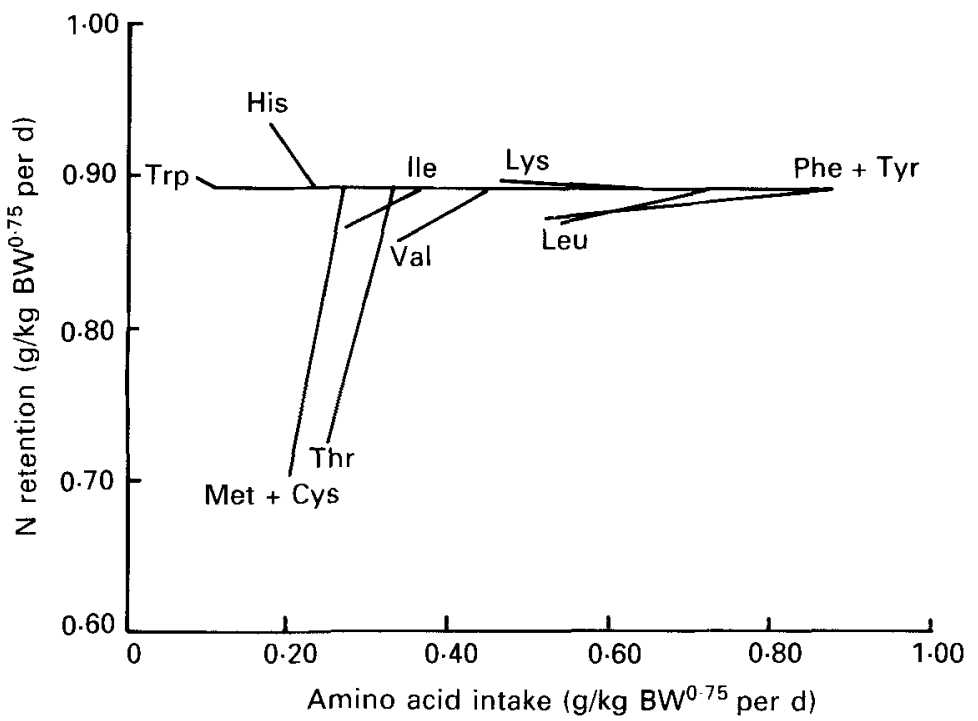

Fig. 2. Expt 2. The effects on nitrogen retention of deleting $22 \%$ ( $36 \%$ for phenylalanine (Phe) and tyrosine (Tyr)) of each essential amino acid. Trp, tryptophan; His, histidine; Met, methionine; Cys, cystine; Thr, threonine; Ile, isoleucine; Val, valine; Lys, lysine; Leu, leucine. BW, body-weight.

Table 8. Expt. 3. Nitrogen metabolism of pigs given diets with partial deletion of individual amino acids

\begin{tabular}{|c|c|c|c|c|c|c|}
\hline Treatment & Diet & NI & $\mathrm{UN}^{*}$ & $\mathrm{NR}^{*}$ & $\mathrm{ABV}^{*}$ & BV* \\
\hline (l) & High-control & 1.42 & 0.51 & 0.81 & 0.61 & 0.73 \\
\hline (2) & Threonine & 1.43 & 0.61 & 0.71 & 0.54 & 0.66 \\
\hline (3) & Valine & $1 \cdot 43$ & 0.56 & 0.75 & 0.57 & 0.69 \\
\hline (4) & $\begin{array}{l}\text { Methionine } \\
\text { +cystine }\end{array}$ & 1.43 & 0.60 & 0.71 & 0.54 & 0.67 \\
\hline (5) & Isoleucine & 1.44 & 0.55 & 0.77 & 0.58 & $0 \cdot 70$ \\
\hline (6) & Leucine & $1 \cdot 42$ & 0.54 & 0.77 & 0.59 & 0.71 \\
\hline (7) & $\begin{array}{l}\text { Phenylalanine } \\
\text { + tyrosine }\end{array}$ & 1.44 & 0.66 & 0.67 & 0.50 & 0.63 \\
\hline (8) & Lysine & 1.42 & 0.59 & 0.72 & 0.55 & 0.67 \\
\hline (9) & Histidine & 1.43 & 0.52 & 0.80 & 0.61 & 0.72 \\
\hline \multirow[t]{2}{*}{ (10) } & Tryptophan & 1.43 & 0.59 & 0.73 & 0.55 & 0.67 \\
\hline & Pooled SE & 0.006 & 0.017 & 0.016 & 0.012 & 0.011 \\
\hline
\end{tabular}

NI, $\mathrm{N}$ intake ( $\mathrm{g} / \mathrm{kg}$ body-weight ${ }^{0 \cdot 75}$ per $\left.\mathrm{d}\right) ; \mathrm{UN}$, urinary $\mathrm{N}\left(\mathrm{g} / \mathrm{kg}\right.$ body-weight ${ }^{0 \cdot 75}$ per $\left.\mathrm{d}\right) ; \mathrm{NR}, \mathrm{N}$ retention $(\mathrm{g} / \mathrm{kg}$ body-weight ${ }^{0.75}$ per $\mathrm{d}$ ); $\mathrm{ABV}$, apparent biological value; $\mathrm{BV}$, biological value.

* Means adjusted for the effects of period and $\mathrm{N}$ intake.

amino acids); the lower NR in treatment 3 compared with treatment 2 was due to the low NI. NR was expressed as a proportion of the absorbed N (ABV) or, with correction for UN and FN losses on the protein-free diet, as BV. Expressed in these terms, the results demonstrated that the synthetic amino acid mixture with the amino acid composition of casein could replace casein protein without significant difference in $\mathrm{N}$ utilization.

\section{Expt 2}

The mean value of FN excretion was 0.105 (SE 0.0022) $\mathrm{g} \mathrm{N} / \mathrm{kg} \mathrm{BW}^{0.75}$ per d. As there were no significant differences between treatments in $\mathrm{FN}$ excretion, this value was used for the 


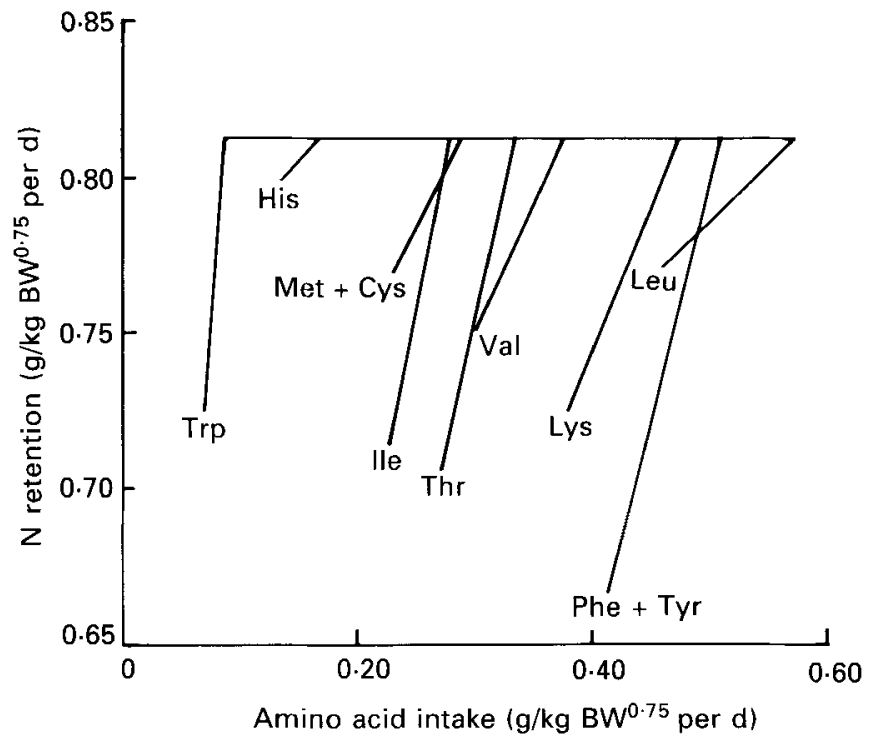

Fig. 3. Expt 3. The effects on nitrogen retention of deleting $20 \%$ of each essential amino acid. Trp, tryptophan; His, histidine; Met, methionine; Cys, cystine; Thr, threonine; Ile, isoleucine; Val, valine; Lys, lysine; Leu, leucine. BW, body-weight.

calculation of NR, BV and ABV. The results for each treatment are shown in Table 7 . The responses to the deduction of individual amino acids were expressed in terms of NR. Fig. 2 shows these responses to reductions in the daily amino acid intake. Only the omissions of methionine + cystine and threonine gave significantly $(P<0.001)$ lower NR than the high-control treatment. In the other treatments NR was either unchanged or improved in response to the deduction of essential amino acids. The simple linear model shown in Fig. 1 was used to calculate the proportion of each essential amino acid which was surplus to an ideally balanced pattern.

\section{Expt 3}

The mean value of FN excretion was 0.115 (SE 0.0202) $\mathrm{g} \mathrm{N} / \mathrm{kg} \mathrm{BW}^{0.75}$ per $\mathrm{d}$. The values of NR, ABV and BV for each treatment are shown in Table 8 . The responses of NR to daily amino acid intake are shown in Fig. 3. For each essential amino acid except histidine, a $20 \%$ deduction was sufficient to make it in turn the first limiting amino acid in the diet. It was, therefore, possible to calculate a pattern in which each essential amino acid would be equally limiting. Expressed relative to lysine $=100$ this had threonine 72 , valine 75 , methionine + cystine 63 , isoleucine 60 , leucine 110 , phenylalanine + tyrosine 120 , tryptophan 18 . No estimate was made for histidine.

\section{Expt 4}

The mean value of FN excretion was 0.086 (SE 0.0151) $\mathrm{g} \mathrm{N} / \mathrm{kg} \mathrm{BW}^{0.75}$ per $\mathrm{d}$. The values for NR, ABV and BV for each treatment are shown in Table 9. The responses of NR to the ratio, essential:non-essential amino acids (and to daily lysine intake) are shown in Fig. 4. Maximum NR was achieved when the ratio, essential: non-essential amino acids was 50:50 or $57: 43$, with lysine at 7 or $8 \mathrm{~g} / 16 \mathrm{~g} \mathrm{~N}$, and these treatments gave a significantly $(P<0 \cdot 05)$ higher rate of NR than the "ideal protein' pattern recommended by the Agricultural Research Council (1981). A broken line model was fitted to these values and from this the optimal ratio, essential : non-essential amino acids was estimated to be $45: 55$. 
Table 9. Expt 4. Nitrogen metabolism of pigs given diets with various ratios of essential: nonessential amino acids (EAA: NEAA). The pattern of amino acids proposed by the Agricultural Research Council (1981) is also given (diet 5)

\begin{tabular}{|c|c|c|c|c|c|c|c|}
\hline Diet & EAA: NEAA & $\begin{array}{c}\text { Lysine } \\
(\mathrm{g} / \mathrm{l} 6 \mathrm{~g} N)\end{array}$ & $\mathrm{NI}$ & $\mathrm{UN}^{*}$ & $N^{*}$ & $\mathrm{ABV}^{*}$ & $B V^{*}$ \\
\hline (1) & $36: 64$ & 5.0 & $1 \cdot 31$ & $0 \cdot 34$ & 0.88 & 0.72 & 0.84 \\
\hline (2) & $43: 57$ & 6.0 & $1 \cdot 30$ & 0.25 & 0.96 & 0.79 & 0.90 \\
\hline (3) & $50: 50$ & 7.0 & $1 \cdot 30$ & $0 \cdot 21$ & 1.00 & 0.83 & 0.93 \\
\hline (4) & $57: 43$ & $8 \cdot 0$ & 1.31 & $0 \cdot 23$ & 0.99 & 0.81 & 0.92 \\
\hline (5) & $45: 55$ & 7.0 & 1.30 & 0.26 & 0.95 & 0.78 & 0.89 \\
\hline Pooled SE & & & 0.004 & 0.015 & 0.014 & 0.012 & 0.011 \\
\hline
\end{tabular}

$\mathrm{NI}, \mathrm{N}$ intake $\left(\mathrm{g} / \mathrm{kg}\right.$ body-weight ${ }^{0.75}$ per d); UN, urinary $\mathrm{N}\left(\mathrm{g} / \mathrm{kg}\right.$ body-weight ${ }^{0.75}$ per $\left.\mathrm{d}\right) ; \mathrm{NR}, \mathrm{N}$ retention $(\mathrm{g} / \mathrm{kg}$ body-weight ${ }^{0.75}$ per d); $A B V$, apparent biological value; $B V$, biological value.

* Means adjusted for the effects of period and $\mathrm{N}$ intake.

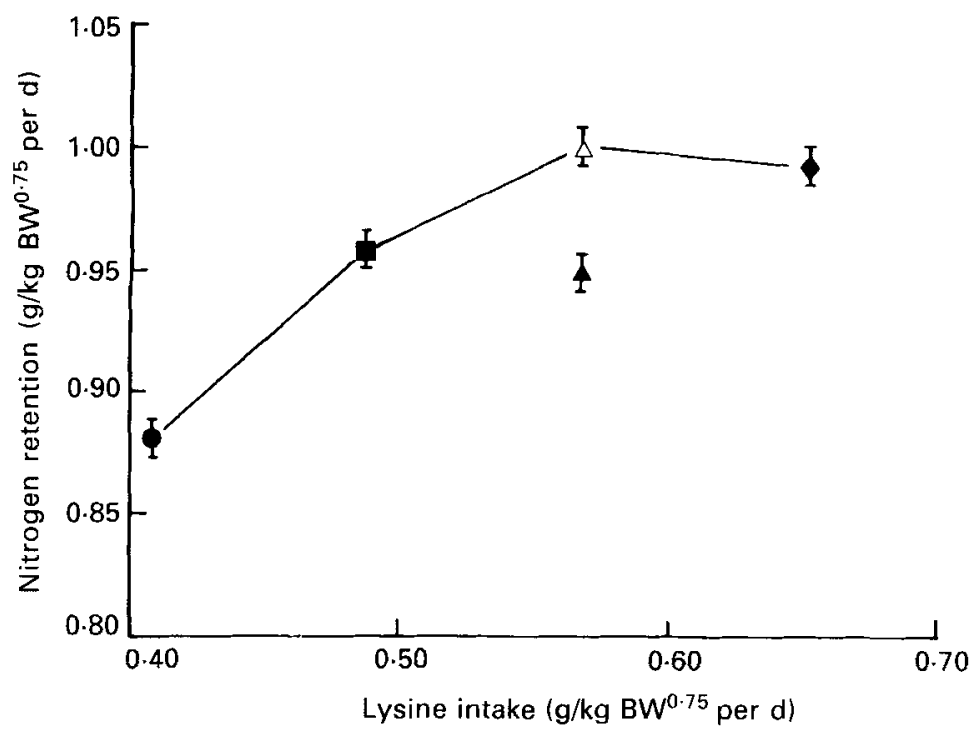

Fig. 4. The effects of varying the ratio; essential amino acids (EAA): non-essential amino acids (NEAA). The EAA were in the proportion deduced from the results of Expt 3 (see p. 85). The ratio, EAA: NEAA was (O), 36:64; $(\square), 43: 57 ;(\triangle), 50: 50,(\bullet), 57: 43$. The amino acid pattern proposed by the Agricultural Research Council (1981) was also included (A). All diets supplied $1.3 \mathrm{~g} \mathrm{~N} / \mathrm{kg}$ body-weight (BW) ${ }^{0.75}$ per d.

\section{Expt 5}

The results are shown in Table 10. There were no significant differences in daily amino acid flow between the animals fed on the protein-free and those fed on the test diet suggesting that the amino acids in these semi-synthetic diets were absorbed completely before the terminal ileum.

\section{DISCUSSION}

Amino acids surplus to the animal's requirement are degraded and their $\mathrm{N}$ is excreted. When dietary energy is limiting, amino acids are oxidized and used as an energy source. In 
Table 10. Expt 5. Amino acid digestibility and daily amino acid flow at the terminal ileum in pigs given the semi-synthetic diet

\begin{tabular}{lccccc}
\hline & \multicolumn{2}{c}{ Digestibility } & & \multicolumn{2}{c}{ Amino acid flow $(\mathrm{g} / \mathrm{d})$} \\
\cline { 2 - 3 } \cline { 5 - 6 } Amino acid & $\begin{array}{c}\text { Semi-synthetic } \\
\text { diet }\end{array}$ & $\begin{array}{c}\text { Protein-free } \\
\text { diet }\end{array}$ \\
\cline { 2 - 3 } & Apparent & True & & & \\
Threonine & 0.850 & 1.018 & & 1.41 & 1.41 \\
Valine & 0.886 & 1.022 & & 0.92 & 0.73 \\
Isoleucine & 0.878 & 0.988 & & 0.74 & 0.45 \\
Leucine & 0.920 & 1.090 & & 0.98 & 1.00 \\
Tyrosine & 0.911 & 1.077 & & 0.57 & 0.56 \\
Phenylalanine & 0.910 & 1.088 & & 0.54 & 0.58 \\
Histidine & 0.881 & 1.094 & & 0.49 & 0.66 \\
Lysine & 0.939 & 1.101 & & 0.63 & 0.61 \\
Arginine & 0.846 & 1.089 & & 0.53 & 0.73 \\
Methionine & 0.968 & 1.116 & & 0.20 & 0.18 \\
Cystine & 0.390 & 0.593 & & 0.44 & 0.55 \\
SED & 0.0385 & 0.0514 & & \\
\hline \hline
\end{tabular}

SED, standard error of difference.

the present experiments non-protein energy was supplied generously to prevent energy being a limiting factor for protein accretion.

In Expts 2 and 3 the changes in NR when dietary essential amino acids were deducted from the control pattern were used to calculate the optimum balance between the essential amino acids. The optimum pattern calculated includes the amino acids required to meet the obligatory $\mathbf{N}$ losses. There is in any case some doubt as to the correctness of subtracting the obligatory $\mathbf{N}$ losses in these calculations. Obligatory $\mathbf{N}$ losses were measured as the $\mathbf{N}$ output of animals given a protein-free diet. As protein is essential for both growth and maintenance, NR is affected not only by the quality of the dietary protein, but also by the level of protein intake. Although all animals had approximately the same daily NI, it was not possible to ensure that every animal had exactly the same amount of N. First, although the feeding scale was based on body-weight, the animals were not weighed daily during the experiments, and their mean weights were somewhat different. Second, the animals did not always eat all the food they were offered. There were, therefore, some small differences in NI between animals. The results were accordingly adjusted for differences in NI by regression analysis.

The amino acids in the diets were mainly from casein, which is highly digestible by pigs of this body-weight (Kies et al. 1986). In all treatments, apart from those with amino acid deletions, all other dietary conditions (e.g. dietary energy and fibre) were the same. As the period used for urine collection was not long enough for faeces collection (because of the error arising from the variable retention time in the gut of the small quantity of faeces with these diets) faeces were collected for the last $10 \mathrm{~d}$ of each balance, and a mean value of FN for all pigs was used in the calculations.

Synthetic amino acids were used to vary the amino acid composition of the experimental diets. The efficiency of utilization of free amino acids by the animal can be affected by the frequency of feeding. Lysine was the first free amino acid to be examined in this context (Walz, 1972; Batterham, 1979). Compared with protein-bound amino acids, free amino acids pass more rapidly through the stomach and are absorbed in the small intestine (Rolls et al. 1972; Buraczewska et al. 1978). Protein synthesis requires that all necessary amino acids are available to the tissues at the same time. Batterham (1979) suggested that the use 
of free amino acids in a conventional diet to estimate amino acid requirements could lead to an overestimate especially when animals were fed only once daily. The efficiency of utilization of the free lysine could be improved by increasing the frequency of feeding (Batterham, 1974, 1979; Batterham \& O'Neill, 1978; Buraczewska \& Buraczewski, 1980). However, the errors arising from the use of free amino acids in these experiments are thought to be small because (1) compared with other protein sources, casein is one of the most fully and rapidly digested (Kies et al. 1986); (2) not only one, but almost all the essential amino acids were used in each experimental diet so that a balanced mixture was being supplied; (3) instead of feeding the animals once daily, the animals were fed three times daily. M. F. Fuller, H. S. Willcox and A. Cadenhead (unpublished results) used intragastric infusion to study the efficiency of replacing casein with its constituent amino acids and showed that the two diets were equally utilized when NR per unit $\mathrm{N}$ apparently absorbed was used as the criterion of response.

As shown in Fig. 2, there were improvements in NR when certain essential amino acids were removed from the amino acid mixture in the casein protein pattern, suggesting that imbalances between essential amino acids depressed NR; even with casein protein the imbalance between the essential amino acids was sufficient to depress NR. These results suggest that the use of only the first limiting amino acid (as in chemical score) does not describe accurately enough dietary protein quality. The amino acids which, when removed from the casein protein pattern, improved NR were tryptophan, lysine, and phenylalanine + tyrosine. The deduction of isoleucine, leucine or valine had little effect. The lowest NR in response to deduction was with methionine + cystine, suggesting that this pair of amino acids was first limiting in casein protein, whilst the second limiting amino acid was threonine.

In the second experiment, deduction of histidine improved NR; in the third experiment there was still no significant response in NR to a further $20 \%$ deduction in histidine. Whether this means that the histidine requirement is even lower, or that there is a bigger body reserve of histidine than of other amino acids, is not clear.

As shown in Fig. 3, all deductions, except for histidine, were sufficient to make the amino acid deducted first limiting. When calculated in relation to the first limiting amino acid (phenylalanine + tyrosine) in the control pattern the calculated optimum balance amongst the essential amino acids was, relative to lysine $=100$, methionine + cystine 63 , threonine 72 , tryptophan 18 , valine 75 , isoleucine 60 , leucine 110 , phenylalanine + tyrosine 120 .

The surpluses of some essential amino acids relative to the ideally balanced pattern were used as sources of $\mathrm{N}$ for non-essential amino acids. The results of Expt 4 (Fig. 4) clearly show this. Based on these results the optimum ratio, essential: non-essential amino acids was at least $45: 55$, and the optimum balance of amino acids $(\mathrm{g} / 16 \mathrm{~g} \mathrm{~N})$ was thus lysine 6.5 , methionine + cystine $4 \cdot 1$, threonine $4 \cdot 7$, tryptophan $1 \cdot 2$, valine $4 \cdot 9$, isoleucine $3 \cdot 9$, leucine $7 \cdot 2$, phenylalanine + tyrosine $7 \cdot 8$.

The dietary ideal protein determined in these experiments is based on the assumption that casein and the synthetic animo acids used are completely absorbed in the small intestine, and thus describes the intrinsic needs of the pig. To use the results as a reference pattern in evaluating the quality of dietary proteins, and for practical diet formulation, amino acid digestibility (measured at the terminal ileum) must also be considered. The pattern describes the total requirements of the pig, that is, its requirements for both maintenance and tissue accretion.

The authors gratefully acknowledge the financial contribution of Eurolysine SA. 


\section{REFERENCES}

Agricultural Research Council (1981). The Nutrient Requirement of Pigs. Slough: Commonwealth Agricultural Bureaux.

Batterham, E. S. (1974). The effect of frequency of feeding on the utilization of free lysine by growing pigs. British Journal of Nutrition 31, 237-242.

Batterham, E.S. (1979). Amino acid availability in pig diets with special reference to natural proteins and synthetic amino acids. In Recent Advances in Animal Nutrition-1979, pp. 11-22 [W. Haresign and D. Lewis, editors]. London: Butterworths.

Batterham, E. S. \& O'Neill, G. H. (1978). The effect of frequency of feeding on the response by growing pigs to supplements of free lysine. British Journal of Nutrition 39, 265-270.

Bender, A. E. (1965). The balancing of amino acid mixtures and proteins. Proceedings of the Nutrition Society 24, $190-197$.

Buraczewska, L. \& Buraczewski, S. (1980). Protein utilization of diets supplemented with free lysine or protein concentrate in pigs fed one or four meals daily. In Protein Metabolism and Nutrition, pp. 307-3111 [H. J. Oslage and K. Rohr, editors]. EAAP Publication no. 27.

Buraczewska, L., Zebrowska, T. \& Buraczewski, S. (1978). The rate of passage of synthetic lysine and dietary protein from the stomach to the intestine in pigs. Roczniki Nauk Rolniczych Series B, 99, 107-112.

Cole, D. J. A. (1978). Amino acid nutrition of the pig. In Recent Advances in Animal Nutrition - 1978, pp. 59-72 [W. Haresign and D. Lewis, editors]. London: Butterworths.

Cole, D. J. A., Yen, H. T. \& Lewis, D. (1980). The lysine requirements of growing and finishing pigs - the concept of an ideal protein. In Protein Metabolism and Nutrition, pp. 658-668 [H. J. Oslage and K. Rohr, editors] EAAP Publication no. 27.

Davidson, J., Mathieson, J. \& Boyne, A. W. (1970). The use of automation in determining nitrogen by the Kjeldahl method, with final calculation by computer. Analyst 95, 181-193.

Fuller, M. F. (1978). Amino acids in the nutrition of the pig. Rowett Research Annual Report 34, $116-128$.

Fuller, M. F. \& Chamberlain, A. G. (1982). Protein requirement of pigs. In Recent Advances in Animal Nutrition -1982, pp. 175-186 [W. Haresign, editor]. London: Butterworths.

Fuller, M. F., Livingstone, R. M., Baird, B. A. \& Atkinson, T. (1979). The optimal amino acid supplementation of barley for the growing pig. 1. Response of nitrogen metabolism to progressive supplementation. British Journal of Nutrition 41, 321-331.

Henry, Y. (1980). Protein and amino acid requirements of growing pigs. In Protein Metabolism and Nutrition, pp. 634-655 [H. J. Oslage and K. Rohr, editors]. EAAP Publication no. 27.

Kies, A. K., Moughan, P. J. \& Smith, W. C. (1986). The apparent and true ileal digestibility of nitrogen and amino acids in lactic casein for the growing pig. Animal Feed Science and Technology 16, 169-178.

Lawes Agricultural Trust (1982). Genstat V, Mark 4.04. Harpenden, Hertfordshire: Rothamsted Experimental Station.

Low, A. G. (1980). Amino acid use by growing pigs. In Recent Developments in Animal Nutrition-1980, pp. 141-156 [W. Haresign, editor]. London: Butterworths.

Lucas, B. \& Sotelo, A. (1980). Effect of different alkalies, temperature and hydrolysis times on tryptophan determination in pure protein and foods. Analytical Biochemistry 109, 192-197.

Moore, S. (1963). On the determination of cystine as cysteic acid. Journal of Biological Chemistry 238, $235-237$.

Rolls, B. A., Porter, J. W. G. \& Westergarth, D. R. (1972). The course of digestion of different food proteins in the rat. 3. The absorption of proteins given alone and with supplements of their limiting amino acids. British Journal of Nutrition 28, 283-293.

Spackman, D. H., Stein, W. H. \& Moore, S. (1958). Automatic recording apparatus for use in the chromatography of amino acids. Analytical Chemistry 30, 1190-1206.

Walz, O. P. (1972). Die Wirkung kombinierter Lysin-Methionin-Zulagen und der Einfluss des Zeitpunktes ihrer Verabreichung auf die biologische Wertigkeit von Haferrationen beim Schwein. Zeitschrift für Tierphysiologie, Tierernährung und Futtermittelkunde 30, 143-144.

Wiesemüller, W. (1983). Physiological basis of the protein requirements of pigs. Critical analysis of allowances In Protein Metabolism and Nutrition, pp. 405431 [M. Arnal, R. Pion and D. Bonin, editors]. EAAP Publication no. 31. Paris: INRA.

Yen, H. T., Cole, D. J. A. \& Lewis, D. (1986). Amino acid requirements of growing pigs. 7. The response of pigs from 25 to $55 \mathrm{~kg}$ live weight to dietary ideal protein. Animal Production 43, 141-154. 